American J. of Engineering and Applied Sciences 4 (3): 372-379, 2011

ISSN 1941-7020

(C) 2014 M. Manzouri et al., This open access article is distributed under a Creative Commons Attribution

(CC-BY) 3.0 license

\title{
Order Management in Supply Chain: A Case Study in Automotive Companies
}

\author{
${ }^{1}$ Malihe Manzouri, ${ }^{1}$ Mohd Nizam Ab Rahman and ${ }^{2}$ Haslina Arshad \\ ${ }^{1}$ Department of Mechanical and Materials Engineering, \\ Faculty of Engineering and Built Environment, \\ ${ }^{2}$ Department of Information Technology, \\ Faculty of Information Science and Technology, \\ University Kebangsaan Malaysia, Kuala Lumpur, Malaysia
}

\begin{abstract}
Problem statement: Predicting customer's future orders had an essential role in planning appropriate strategy in a Supply Chain Management (SCM) implementation. Purpose of this study was to identify how predicting future orders can facilitate managing activities across companies. Approach: A case study conducted in four Iranian automotive organisations to understand the actual results of order prediction in managing organisational processes. Results: Results of case study highlighted that more than $86 \%$ of activities completed before actual orders were received in these organisations. Conclusion: The findings show the high level of order management in these organisations which are the results of accessing to the right and timely information. This study would give invaluable information to all researchers who investigate the impact of order prediction in fulfilling organisational activities.
\end{abstract}

Key words: SCM implementation, case study, automotive companies, Point Of Sale (POS), order prediction

\section{INTRODUCTION}

The notion of SCM has risen to prominence over the past decade. $13.5 \%$ of the concurrent session titles contained the notion of the supply chain at 1995 Annual Conference of the Council of Logistics Management. The number of sessions containing this notion rose to $22.4 \%$ just two years later. This notion often described executive responsibilities in organisations (Sabri and Beamon, 2000) and become a hot topic in all periodicals on manufacturing, distribution, marketing, customer management and transportation (Wong and Wong, 2007). Supply chain Managers always tried to design effective business to meet customer demands better than competitors. For instance Wang (2010) and Radhakrishnan et al. (2009) highlighted that optimising processes such as production, distribution and inventory with using appropreat information improve SCM performance and decrease the cost. So, all processes and activities in designing, producing and transporting should be done with the high quality and low cost. During these efforts managers faced many problems such as lack of skills and information sharing defficeincy (Wang, 2010) order fluctuation and demand variations (Chen et al., 2000). Therefore, they are considering that how the resources of their suppliers and customers can be useful to recover their problems. These attempts to align goals, share resources and cooperate among organisation boundaries are the essence of SCM (Vonderembse et al., 2006; Fox et al., 2000).

In the today competitive global market, selecting a suitable method of production is an important decision which should be taken by managers to rapid respond to the customers. Often, made to stock or make-to-order (or engineer-to-order) styles have been chosen (Sahin and Robinson, 2005). However, there are some limitations in both methods which often create problems in managing orders in organisations. For instance, in made to order method products always are available in warehouse to satisfy customer orders but the storage of these produced products are costly. Besides, it is possible that many of those products remain in warehouse and will never be sold so all resources (raw materials, workers, equipments) will be wasted. On the other hand, although the method of make to order do not have the limitations of made to stock method, it has own limitations. Very often,

Corresponding Author: Malihe Manzouri, Department of Mechanical and Materials Engineering, Faculty of Engineering and Built Environment, University Kebangsaan Malaysia, Kuala Lumpur, Malaysia 
organisations lost their customers because the products are not available in warehouse when customer orders are received (Manzouri et al., 2011). So, it is necessary for organisations to find the best techniques of forecasting to predict customers future orders. Based on this prediction, organisations can organise all their processes and activities not only in production but also warehousing and distribution systems.

Automotive companies were considered in this study to investigate the roles of forecasting in managing activities. The significant impacts of automotive industry on the socio-economic life of mankind are demonstrated in many studies (Rosli, 2006). It affects on economic development, industrial companies, technologies, managerial practices and standard of living. Due its importance, this industry is considered as modern industry and the single largest manufactures sector in the world (Rosli, 2006). Automotive companies in Iran have been considered as it is the most important and strategic industries in this country. Besides, it makes a large contribution to entrepreneurship, gross domestic product, external trade and employment in this country. These organisations intended to export their products especially to Malaysia, Syria, Cuba and Venezuela. For instance, in 2000s Iranian organisations exported about 13,300 tonnes of tires, worth about 22 million USD (Schwartz, 2011). Irankhodro company gained about 40 million USD from exporting car parts to Sudan in 2006.

In this study based on (Manzouri et al., 2011) suggestion's method, three Iranian automotive organisations were asked to predict and manage their future orders. This article is outlined into two parts. (A) Focusing on the role of forecasting in a supply chain implementation through review of selected SCM literature. (B) Identifying the impact of prediction in managing activities in practice among automotive organisations in Iran through conducting a case study. Finally, the key issues which merit special attention in the future will be highlighted.

The role of forecasting in a supply chain implementation: Predicting customer's future orders has an essential role in planning appropriate strategy in a SCM implementation. Recognising the best methods of prediction and accessing the critical information which lead managers to make best prediction of future orders are the most important issue in the today global SCM. (Chopra and Meindl, 2007) defined some characteristics of appropriate demand prediction as; (1) prediction process should evaluate the expected forecast value and measure of forecast error, otherwise it will be wrong, (2) short-term forecasts are more accurate than long-term forecasts. Short-term forecasts have a smaller standard deviation of error relative to the mean than long-term forecasts, (3) aggregate forecasts have smaller standard deviation of error relative to the mean rather disaggregate forecasts thus they are usually more accurate.

Generally, organisations which are farther up from customer in a supply chain will receive the more distortion of information. Therefore, they had to consider the various prediction factors before any technique of prediction be selected, which are included the past orders, lead time of goods, promotion planning, economic situations, advertising planning and follow competitor's actions. Hence, managers should pay attention to all these factors together to make proper decision about their future orders. For instance organisations should consider to the economic situations not only in their local area but also all over the world to be aware of future demands. Moreover, it is very helpful to attend the strategies of the successful organisations and follow their techniques. Beside all above factors, knowledgeable employees and proper software are required to analyse all mentioned information and make appropriate decision. On the other hand, the predictions techniques can be classified into the four various types such as; qualitative, time series, causal and simulation. The qualitative type relies on the human judgment which is suitable when a little historical data is available. Otherwise, the historical demands information is used in the time series method. On the other hand, the decision would be made upon the correlated between demand and environmental factors in the causal technique. In contrast, the time series and causal techniques are combined in the simulation method. However, it is very difficult for organisations to choose the proper method of forecasting. In this regard, a multiple prediction method is more effective than using one method alone (Chopra and Meindl, 2007).

In addition, the effective prediction steps should be recognized in each organisation. For instance organisations should realise the purpose of prediction, recognise the customer segments, combine order planning in the whole supply chain, identify the main important factors which affect the order forecasting, recognise the proper method of prediction and apply error measurement for their prediction systems. More importantly, although IT system has a critical role in the forecasting systems and error measurement, sometimes managers should rely on the human intuition in order to predict future orders.

Kovalchuk and Fasli (2008) proposed the Genetic Programming (GP) and Neural Network (NN) learning methods to predict the lower price among the ones offers by all sellers for each goods. They emphasised that these techniques are used for making financial 
forecasts in various business domains. In addition, Wagner (2010) conducted a study to compare competing techniques in prediction of daily demand in cash supply chains. These results highlighted that using advanced prediction technique are beneficial for daily prediction. Manzouri at al. (2011) proposed a framework (Fig. 1) for using Point Of Sale (POS) data in forecasting customer's orders.

Shepard and Greene (2006) demonstrated that a case study is based on an in-depth investigation of a single individual, group, or event which is common in social science and used to explore causation in order to find underlying principles. In this method a systematic way of looking at events, collecting data, analysing information and reporting the results are provided for researcher to gain a sharpened understanding of why the instance happened as it did and what might become important to look at more extensively in future research. On the other hand, this method is not only appropriate to generate hypotheses but also is suitable to test them. Basically, this technique narrows a broad field of study into one easily researchable topic. Furthermore, new and unexpected results might emerge during applying this method which leads to research taking new directions (Shuttleworth, 2008).

Case study is a proper method to be applied in program evaluation studies or studies that track changes in complex systems (Kohn, 1997). In this regards, for understanding the role of forecasting in managing processes and activities across the supply chain the case study methodology is suitable approach to use. Several empirical studies have been employed this method when conducting the link between SCM practice and organisational performance. Manzouri et al. (2010) conducted the study in the Iranian and Malaysian organisation to investigate the important barriers which impded these organizations to apply SCM. Naude (2009) also conducted two case studies in South Africa in the Toyota and Ford companies to provide some new insights into the development and implementation of SCM in the automotive organisations. Hence, since in this study the impact of using proper information in predicting future orders in the real organisation need to be investigated the case study methodology is suitable approach to use.

To gain a rich understanding about the impact of having proper information in managing the organisational activities before the actual orders were received; a case study was conducted in three Iranian automotive organisations. This case study has been done based on the framework (Fig. 1) which is suggested by Manzouri et al. (2011). According to this framework, after accepting a new order in an organisation (Fig. 1), its data should be shared to the all members of the supply chain (such as distributer, wholesaler, factory) via internet before doing any operation (i.e., sending external order, preparing semifinished part, documentation).

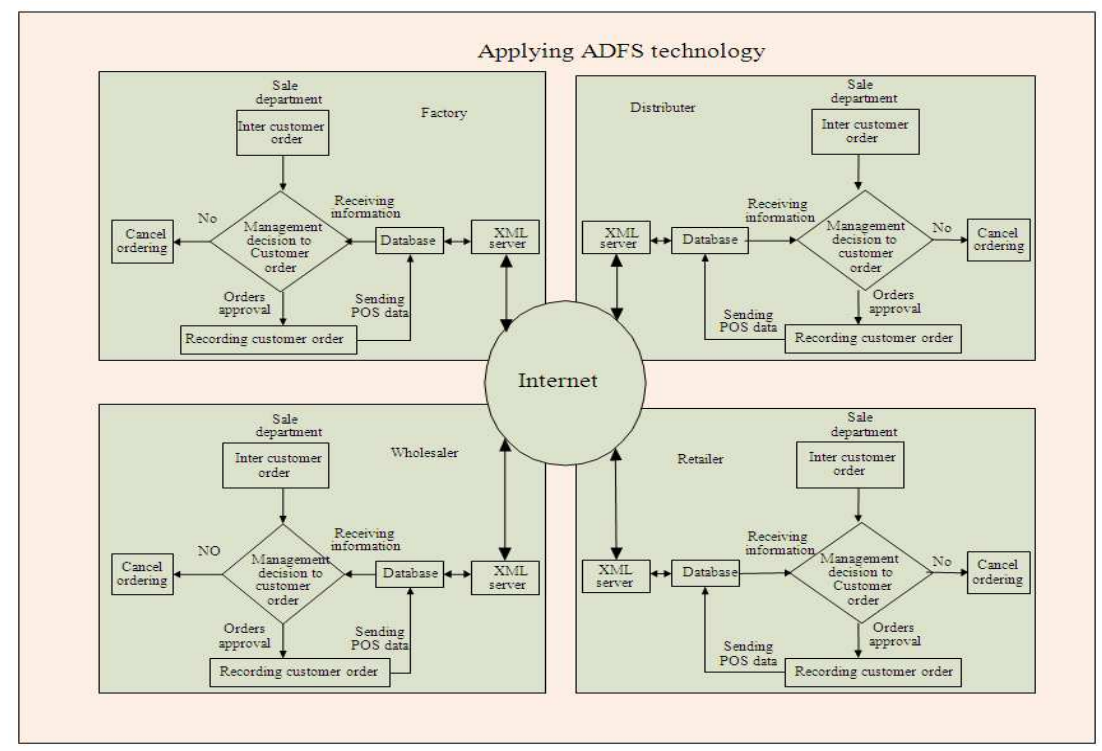

Fig. 1: Framework for sharing POS data, (Manzouri et al., 2011) 
For instance, retailer should store its POS data in its database immediately after accepting the new orders from its customers. Besides, the latest data of others internal departments in retailer company such as inventory and distribution should be stored in this database. This framework suggested that all partners can access the database of retailer to extract their required data. Based on this data (included POS data and other data which is stored in database) all suppliers of the retailer can predict the future orders that might be received from retailer. Since the data of retailer is real and accurate and have been shared timely, all suppliers can plan their future activities at the right time to satisfy retailer demands. So, there is no need to use the method of the make to stock which is costly or no need to use the method of the made to order which might face organisations out of stock problems. Thus, according to this framework, all units of a supply chain should share their information as retailer shared to make access for all tiers in their database.

Mailing and emailing address lists of 20 automotive companies were found from which is the largest database of Iranian organisations. Ten Iranian automotive companies were chosen to participate in this case study. These organisations were chosen from various range of company's size (from large to small organisations). From those, only one automotive company (named $\times$ Company) accepted to participate with three of their suppliers. Other organisations claim that they are so busy and did not have any time to be participated. They do not tend to change their workflow to implement proposed framework because they are not confident about outcomes. Other organisations do not have knowledgeable employees and proper equipment such as software or hardware.

The X Company has more than 101 and less than 300 full time employees, which means that they did not belong to the large organisations size. The organisations were contacted through Email and telephone because of the distance problem. The data was captured between Septembers 2010-February 2011 in the Persian language.

The X Company produces an assembled product for a main automotive manufacture in Iran and the Y1, Y2 and Y3 Companies supply three part of that assembled product for X Company. This company is a privet Iranian firm which was established in 1988. At first it just produced the motorcycle parts. In the middle of 1995, it started producing polymer parts for automotive manufacturer companies. It is the first company which was successful in designing and manufacturing the polymer lights in Iran. So, it is supplying polymer lights for big automotive manufacture companies in Iran. Besides this company cooperate with Korean, Taiwanese, Indian and Chinese companies in producing their products. It has the ISO9002 and QS9000 certificates from BVQI institute and ISOTS16949 from MIC institute in UK. Additionally, four its products have the CE certificate. SCM was implanting in this company since 1993. Lack of knowledgeable employees, lack of Internet connectivity, LAN problem in partners companies, changing in planed orders were considered as important problems in this company during implementing SCM. This company exposed that "we are producing more products for stocking in inventory to countermeasure with changing planed orders". However, this method faced this company with increasing product stock and waste of money and products. Y1, Y2 and Y3 Companies are the subsidiaries of $\mathrm{X}$ Company which not only produce semi-finished product for $\mathrm{X}$ Company, but also produce for other Iranian automotive companies.

The X Company explained their workflow before applying the framework. When the top manager approves order from their customer, the data is recorded in the sale department and then a meeting is conducted with all related internal departments to review this order and to identify the requirements and processes. In this meeting, they classify each department's duty and assign it to them. For instance, if the new order is a product that used to be produced by the X Company, they have to check for the availability of the product in their storage and plan for more production in their production planning department. Otherwise, if the order is a new product which has never been produced by $\mathrm{X}$ company, their tooling and designing department must be involved to prepare the requirements needed. In addition, they have to prepare a distribution system and provide the suitable storage space for the new product. More importantly, the production department should plan and provide the necessary equipments to produce new products timely. The needed budget, workers and raw material of these new orders should be prepared as well. Besides the internal processes, there are many external processes such as providing raw materials, required software and the parts (semi finished products) which should be produced by suppliers. All external orders should be sent by relevant departments that take time to be prepared and sent. For instance, they reported that it usually takes between 7-15 days till the Y1, Y2 and Y3 Companies receive the orders from the day when the decision was made to send the orders to 
them. Meanwhile, there was not any information sharing between the X Company and their suppliers. They just send the data for the product that must be produced by the Y1, Y2 and Y3 Companies such as product's sample and $2 \mathrm{~d}$ and $3 \mathrm{~d}$ drawings.

According to proposed framework (Fig. 1), the X Company accepted to send their POS data right after placing the order in this company to the Y1, Y2 and Y3 Companies. This means that the $\mathrm{X}$ Company sends the amount and kind of products that their customers needed, the name of customers and the date that these products should be ready (as their POS data) before reviewing the order or doing any other processes (internal or external). X Company just send POS data to notify the Y1, Y2 and Y3 Companies of its new orders which this company received from its customers. It does not mean that a new order has been placed and sent by the $\mathrm{X}$ Company to the $\mathrm{Y} 1, \mathrm{Y} 2$ and $\mathrm{Y} 3$ Companies. Accordingly, there is no time delay (7-15 days as usual) for the Y1, Y2 and Y3 Companies to know about the new orders which is assigned to the $\mathrm{X}$ Company. Since, the Y1, Y2 and Y3 Companies maintained that they did not have IT infrastructure to fully apply the proposed framework (Fig. 1); hence, the $\mathrm{X}$ Company send the POS data via email to them.

"We trust this data and made a plan for our future processes... According to this method, we had adequate time to be prepared and planned for our future orders", the Y1 Company said. Further, the Y1, Y2 and Y3 Companies stated that often when they receive an order from the X Company, their time is tight and they have to rush in all their processes to satisfy their customer. In this case, they reported that "We did not need to rush in providing our requirements such as raw materials, equipping production, distribution and inventory systems, because we had enough time to be prepared."We did not need to put extra shift for our employees in tooling, designing, quality, measurement, production, inventory and financial departments to prepare products in order to satisfy our customer timely", the Y1 Company added. "If we cannot send the products on time to the X Company, we have to pay the very high penalty." On the other hand, the Y2 Company pointed out that, "usually we have problems in providing the raw materials, because it is provided to us by an external supplier in Spain which takes a long time to be received". "Sometimes we had to spend more money to supply the materials timely or buy more materials and store them which might not be used at all." The Y1, Y2 and Y3 Companies believed that sharing the latest POS data gave them an opportunity to provide their raw materials in time or even earlier.
During applying this framework, the Y1, Y2 and Y3 Companies review and analyse the POS data received by the $\mathrm{X}$ Company, to plan their future processes. For instance, the Y1 Company reported that they received the POS data for a part (semi-finished product) that they used to supply for the X Company. In their review, they estimated that there might be some products in the $\mathrm{X}$ Company's store from the previous order and might be remained some in their store as well. They planned to check not only their inventory level but also the inventory level of the X Company to know about the exact amount of this product in both inventories. According to proposed framework, each tier in the supply chain can access to database of its partners to get its needed data. In this case study, the participated companies do have proper equipments (i.e., Internet connectivity, comprehensive data base) to fully implement proposed framework, so Y1 Company received it's required (i.e., the amount of inventory of $X$ Company) data via Email or telephone from $\mathrm{X}$ Company. Thus, the amount of real orders which they will receive from the $\mathrm{X}$ Company was almost clear to them. In this regards, they considered that "it was not necessary to produce more products for safety stock because the amount of future order was almost clear. Producing the safety product took more time and money because more products need more storage space, employees and equipments to be produced, stored and protected. The Y1, Y2 and Y3 Companies mentioned that, "it was not necessary to allocate the costly night distribution system to distribute our products to the $\mathrm{X}$ Company, because we had enough time for the workflow and distribution system". More importantly, "we had enough time to examine the quality of our products before sending them to the X Company" they added.

The Y1, Y2 and Y3 companies were asked about their workflows in satisfying customer orders. They need to prepare raw material, workers and financial support. Besides, they have to organise their production, inventory and distribution systems. In providing these requirements, they must fulfil four important steps which are included the resource finding, negotiations with suppliers, preparing documents and implement phases. For instance, in supplying the raw materials, firstly, they need to find the appropriate resources, secondly, negotiate with these resources to find the best supplier. Thirdly, they must prepare purchase documents and finally send the orders to the selected supplier. According this information, a table is provided which is included all requirements and processes that are necessary for fulfilling those steps. All Y1, Y2 and Y3 companies were asked to define the exact percentages of each process from the beginning to implement and put the information in the table (Table 1-3). 
Am. J. Engg. \& Applied Sci., 4 (3): 372-379, 2011

Table 1: The results of applying proposed framework in Y1 Company

\begin{tabular}{|c|c|c|c|c|c|}
\hline \multirow[b]{2}{*}{ Requirement } & \multicolumn{4}{|l|}{ Process } & \\
\hline & Phase1 (\%) & Phase $2(\%)$ & Phase $3(\%)$ & Phase $4(\%)$ & \\
\hline Raw material & Resource finding 30 & Negotiations 10 & Preparing documents50 & Implement (Supply) 10 & Total 100 \\
\hline Worker & $\begin{array}{l}\text { Prediction for number } \\
\text { and kind of expertise } 10\end{array}$ & Employ 30 & Training 50 & Implement 10 & Total 100 \\
\hline Financial & Cost estimation 20 & Budget planning 20 & Financing 50 & Implement 10 & Total 100 \\
\hline Production & feasibility study 20 & $\begin{array}{l}\text { Designing, tooling, } \\
\text { and production } 30\end{array}$ & $\begin{array}{l}\text { Preparing needed } \\
\text { documents } 45\end{array}$ & Implement 5 & Total 100 \\
\hline $\begin{array}{l}\text { Inventory and } \\
\text { distribution }\end{array}$ & $\begin{array}{l}\text { Preliminary studies } \\
\text { for packaging } 10\end{array}$ & $\begin{array}{l}\text { Planning inventory } \\
\text { and its requirements } 20\end{array}$ & supply requirements 50 & Implement 20 & Total 100 \\
\hline
\end{tabular}

Table 2: The results of applying proposed framework in Y2company

\begin{tabular}{|c|c|c|c|c|c|}
\hline \multirow[b]{2}{*}{ Requirement } & \multicolumn{4}{|l|}{ Process } & \\
\hline & Phase $1(\%)$ & Phase $2(\%)$ & Phase $3(\%)$ & Phase $4(\%)$ & \\
\hline Raw material & Resource finding 30 & Negotiations 30 & Preparing documents 30 & Implement (Supply) 10 & Total 100 \\
\hline Worker & $\begin{array}{l}\text { Prediction for number } \\
\text { and kind of expertise } 30\end{array}$ & Employ 25 & Training 25 & Implement 20 & Total 100 \\
\hline Financial & Cost estimation 20 & Budget planning 30 & Financing 30 & Implement 20 & Total 100 \\
\hline Production & feasibility study 30 & $\begin{array}{l}\text { Designing, tooling } \\
\text { and production } 10\end{array}$ & $\begin{array}{l}\text { Preparing needed } \\
\text { documents } 50\end{array}$ & Implement 10 & Total 100 \\
\hline $\begin{array}{l}\text { Inventory and } \\
\text { distribution }\end{array}$ & $\begin{array}{l}\text { Preliminary studies } \\
\text { its distribution } 10\end{array}$ & $\begin{array}{l}\text { Planning inventory and } \\
\text { for packaging } 20\end{array}$ & $\begin{array}{l}\text { supply requirements } \\
\text { requirements } 60\end{array}$ & Implement 10 & Total 100 \\
\hline
\end{tabular}

Table 3: The results of applying proposed framework in Y3company

\begin{tabular}{|c|c|c|c|c|c|}
\hline \multirow[b]{2}{*}{ Requirement } & \multicolumn{4}{|l|}{ Process } & \\
\hline & Phase $1(\%)$ & Phase $2(\%)$ & Phase $3(\%)$ & Phase $4(\%)$ & \\
\hline $\begin{array}{l}\text { Raw material } \\
\text { documents }\end{array}$ & Resource finding 35 & Negotiations 10 & Preparing 40 & Implement 10 & Total 100 \\
\hline Worker & $\begin{array}{l}\text { Prediction for number } \\
\text { and kind of expertise } 30\end{array}$ & Employ 10 & Training 40 & Implement 20 & Total 100 \\
\hline Financial & Cost estimation 40 & Budget planning 20 & Financing 30 & Implement 10 & Total 100 \\
\hline Production & feasibility study 30 & $\begin{array}{l}\text { Designing, tooling } \\
\text { and production } 30\end{array}$ & $\begin{array}{l}\text { Preparing needed } \\
\text { documents } 30\end{array}$ & Implement 10 & Total 100 \\
\hline $\begin{array}{l}\text { Inventory and } \\
\text { distribution }\end{array}$ & $\begin{array}{l}\text { Preliminary studies } \\
\text { for packaging } 10\end{array}$ & $\begin{array}{l}\text { Planning inventory } \\
\text { and its requirements } 40\end{array}$ & supply equipments 20 & Implement 30 & Total 100 \\
\hline
\end{tabular}

According the proposed framework Y1, Y2 and Y3 Companies can access to their requirement data from the X Company such as POS data, inventory, distribution and so on to make proper decision about their future orders. They believed that based on this information, it will be possible for them to complete phase 1 to 3 before actual orders be received and only phase 4 remain to be done. In implementing this framework, they received data from X Company and started their processes from phase 1-3 (Table 1-3). Company Y1 reported that "we did phase 1-3 of the processes before real orders have been received". The final phase (Table 1) which is depended on the real order was only $11 \%$ of the total processes. This company revealed that "after applying phase 1-3 we just worried about the $11 \%$ of our processes which were not implemented and were waiting the real order to be received. "We found a source to prepare our raw material and conducted meeting with them. Moreover, we provided the requirement document for new order. In this time $90 \%$ of our raw material supply processes were done. It means that we were not worried about the raw material supply and when we received the real order from X Company we just sent our order to the defined company to supply our raw material."

Y2 Company revealed that they planned all their processes (Table 2) according the data that they received from $X$ Company and just $14 \%$ of their processes (implementation phase) remained to be done after receiving the real order. They emphasised their inventory and distribution systems and pointed out that "we planned for new packaging systems, storing space and supplying our new equipments which were the $70 \%$ of our inventory and distribution processes. When real orders received we just completed the remaining phase (30\%)". This company considered that "we always have problems with our packing systems and the storage 
space which take the long time to be designed and provided. In this case after providing phase 1-3 we just worried about the $30 \%$ of total processes."

On the other hand, Y3 Company reported that after applying proposed framework, they needed to complete just $17 \%$ of their processes after receiving real order from X Company as their customer. This company revealed that "during applying this framework we received POS data of a product that we did not use to produce for $\mathrm{X}$ company, in this regard we asked the data of the new product from X Company to review its information and do the feasibility study.

In the second phase we designed $2 \mathrm{~d}$ and $3 \mathrm{~d}$ for new product and its tools. Beside we provided the requirements documents in the third phase. $90 \%$ of production processes which are included phase 1-3 are done (Table 3 ) before actual order be received. Finally when we received the order from X Company we just jumped to the phase 4 to finish the production processes".

On the other hand, the X Company stated that "we are worry about the delay in receiving the parts from the suppliers to feed the production line. Often, all parts of an assembled product are available to the production line except for one part that can stop the production line till it is prepared". They have to pay the penalty to their customer if they delay sending the product. Moreover, all their equipments and employees are waiting just for one part. So when this framework was applied for two months, the $\mathrm{X}$ Company realised an improvement in receiving the parts from the Y1, Y2 and Y3 Companies more timely and accurately.

\section{CONCLUSION}

All three organisations (Y1, Y2 and $\mathrm{Y} 3$ Companies) reported that according this framework they were successful to overcome more than $80 \%$ of workflows problems before actual order is received in their company. On average only $14 \%$ of workflows in these companies remain to be done after receiving the real orders. It means that according to POS data which was shared by X Company, all its suppliers not only manage their activities but also fulfil $86 \%$ of their processes before any order be received from $\mathrm{X}$ Company. This results show the high level of order management in these organisations which are the results of accessing to the right and timely information in Y1, Y2 and Y3 Companies. Based on these results it can be concluded that predicting future orders and managing activities require various kind of information which should be shred across supply chain.
However, Y1, Y2 and Y3 Companies could not talk about the financial profits of managing their orders based on proposed framework because they have many other suppliers and customers and applying this framework in the small scale does not affect their whole workflows. Moreover, their employees are not much expert and their equipments are not adequate to fully apply this framework. Suggesting that they are at the beginning stage of implementing this framework and they need more time to be expert in all stages. They claimed that "maybe in future, we can improve the inventory, distribution and production systems using this framework to decrease the cost and to be more competitive in the market".

\section{REFERENCES}

Chen, F., Z. Drezner, J.K. Ryan and D. Simchi-Levi, 2000. Quantifying the bullwhip effect in a simple supply chain: The impact of forecasting, lead times and information. Manage. Sci., 46: 436-443. DOI: 10.1287/mnsc.46.3.436.12069, pp 201

Chopra, S. and P. Meindl, 2007. Supply Chain Management, Strategy, Planning and Operation. 3rd Edn., Pearson Prentice Hall, ISBN: 0132086085, pp: 536.

Fox, M.S., M. Barbyceanu and R. Teigen, 2000. Agentoriented supply-Chain management. Int. J. Flexible Manufactur. Syst., 12: 165-188. DOI: 10.1023/A:1008195614074

Kohn, L.T., 1997. Methods in Case Study Analysis. The Center for Studying Health System Change Technical Publication No. 2. http://webanketa.com

Kovalchuk, Y. and M. Fasli, 2008. Adaptive strategies for predicting bidding prices in supply chain management. Proceedings of the 10th International Conference on Electronic Commerce, (EC' 08), ACM, New York. DOI: 10.1145/1409540.1409548

Manzouri, M., M.N.A. Rahmana, H. Arshadb and A.R. Ismai, 2010. Barriers of supply chain management implementation in manufacturing companies: A comparison between Iranian and Malaysian companies. J. Chinese Instit. Indus. Eng., 27: 456472 DOI: 10.1080/10170669.2010.526379

Manzouri, M., M.N.A. Rahman, H. Arshad, J.A. Ghani, 2011. Cutting down the difficulties of SCM implementation: A comparison between iranian and malaysian companies. Applied Mech. Mater., 44-47: 3652-3656. DOI: 10.4028/www.scientific.net/AMM.44-47.3652

Naude, M.J.A., 2009. Supply Chain management Problems experienced by South African automotive component manufacturer. University of South Africa. http://uir.unisa.ac.za 
Radhakrishnan, P. V.M. Prasad and M.R. Gopalan, 2009. Optimizing inventory using genetic algorithm for efficient supply chain management. J. Comput. Sci., 5: 233-241. DOI: 10.3844/jcssp.2009.233.241

Rosli, M., 2006. The automobile industry and performance of malaysian auto production. J. Econ. Coopration, 27: 89-114.

Schwartz, L.C.S.W.M., 2011. Turning crisis into opportunity. Sussex Directories, Inc. http://www.psychologytoday.com

Sabri, E.H. and B.M. Beamon, 2000. A multi-objective approach to simultaneous strategic and operational planning in supply chain design. Omega, 28: 581598.

Sahin, F. and E.P. Robinson, Jr., 2005. Information sharing and coordination in make-to-order supply Chains. J. Oper. Manage., 23: 579-598. DOI: 10.1016/j.jom.2004.08.007

Shepard, J.M. and R.W. Greene, 2006. Sociology and You. 1st Edn., Glencoe/McGraw-Hill, New York, ISBN-10: 0078745195, pp: 601.
Shuttleworth, M., 2008. How to choose from the different research method. http://www.experimentresources.com

Vonderembse, M.A., M. Uppal, S.H. Huang and J.P. Dismukes, 2006. Designing supply chains: Towards theory development. Int. J. Prod. Econ., 100: 223-238. DOI: 10.1016/j.ijpe.2004.11.014

Wagner, M., 2010. Forecasting daily demand in cash supply chains. Am. J. Econ. Bus. Admin., 2: 377383. DOI: 10.3844 /ajebasp.2010.377.383

Wang, C. 2010. The influence of information sharing on supply chain management. Phys. Int., 1: 83-89 DOI: $10.3844 /$ pisp.2010.83.89

Wong, W.P. and K.Y. Wong, 2007. Supply chain performance measurement system using DEA modeling. Ind. Manage. Data Syst., 107: 361-381. DOI: $10.1108 / 02635570710734271$ 